\title{
Coagulation Acivity of Moringa oleifera Lam. Seeds
}

\author{
Kalekar Sumita Vijay ${ }^{1}$, Shinde Nanda Waman ${ }^{2}$ \\ Research laboratory, Dept of Botany, K. V. Pendharkar College of Arts, Commerce \& Science, Dombivli (E) 421203. Thane Dist. \\ Mumbai, India
}

\begin{abstract}
Tribal people in India in extreme poverty use unimproved drinking water sources such as surface water and unprotected wells. These water sources become highly turbid during late summer and rainy season. Because of drinking turbid and untreated water, epidemics of water born diseases are of common occurrence in these populations. People drink polluted water because they lack knowledge of proper drinking water treatments and also they cannot afford costly chemical coagulants. Therefore, usage of safe, traditional water treatment agents from natural sources has become essential. Women in rural areas of India treat their water with Moringa oleifera seed powder prior to drinking purpose. Hence in present paper, study on water clearing efficacy of this plant is reported. Results of turbid untreated water samples treated with seed powder of this plant are given.
\end{abstract}

Keywords: Natural coagulants, Moringa oleifera seed powder, rural populations, water clearing efficacy

\section{Introduction}

Water is used for several purposes by humans but the level of purity of water being consumed is very crucial since it has direct effect on health. Conventional treatments of water often include sedimentation, filtration and disinfection. In rural and undeveloped countries people living in extreme poverty are presently drinking highly turbid and microbiologically contaminated water, because they lack knowledge of proper drinking water treatment and they cannot afford costly chemical coagulants. It is well known fact that most of the chemical disinfectants used for antibacterial activity generated various unwanted chemicals which are associated with harmful effects on human health such as hemolytic anemia, cancer risk, nervous system effect and liver effects.

Naturally occurring coagulants are usually presumed safe for human health. Studies on natural coagulants like Moringa oleifera seeds have been carried out. Earlier studies have found Moringa oleifera to be non-toxic and recommended it for use as a coagulant in developing countries. Hardness removal efficiency of Moringa oleifera was found to increase with increasing dosage [6]. $M$. oleifera seeds act as a natural absorbent and antimicrobial agent. It's seed contain $1 \%$ active polyelectrolytes that neutralize the negatively charged colloids in the dirty water. This protein can therefore be useful as nontoxic natural polypeptide for sedimentation of mineral particles and organics in the purification of drinking water. M. oleifera seeds are also acting as antimicrobial agent against variety range of bacteria and fungi [2]. The seed contain number of benzyl isothiocyanates and benzyl glucosinolates which act as antibiotic [5]. It is believed that the seed is an organic natural polymer. The active ingredients are dimeric proteins. The protein powder is stable and totally soluble in water. It has been described as adsorbent and neutralizase negatively charged protein particles in dirty water coagulating them. Flocculation by inter-particle bridging is mainly characteristic of high molecular weight polyelectrolytes. Due to the small size of the $M$. oleifera coagulant protein, a bridging effect may not be considered as the likely coagulation mechanism [6]. It is reported that a recombinant protein in the seed is able to flocculate grampositive and gram-negative bacterial cells. In this case, microorganisms can be removed by settling in the same manner as the removal of colloids in properly coagulated and flocculated water. A general rule of thumb is that powder from one Moringa kernel to two liters of water is a good amount when water is slightly turbid, and to one liter when water is very turbid [1].

Due to the presence of natural coagulants and antimicrobial activity, seed powder was used to coagulate-flocculate or precipitate microbes and turbidity in water [3].

\section{Materials and Methods}

Dried Moringa oleifera seeds were collected from Dombivli . The wings surrounding the seed were removed and fine powder was prepared by using mortar and pestle, sieved and this powder was directly used as coagulant. Water samples for study purpose were collected from ground open well water from Umberli village, near Dombivli, Maharashtra. Treatment to water was given by directly using seed powder.

Turbid open well water sample was treated with Moringa oleifera seed powder at concentrations $50 \mathrm{mg} / 1,100 \mathrm{mg} / \mathrm{l}$, $150 \mathrm{mg} / \mathrm{l}$ separately in three conical flasks and kept on shaker for $45 \mathrm{~min}$ at $110-120 \mathrm{rpm}$ for proper mixing. After removing from shaker the contents of the flask were allowed to settle. Once the treated water samples were kept for sediment settling, they were observed after every one hour to determine exact time duration required for complete sedimentation.

\section{Observation}

It was observed that maximum reduction in turbidity was achieved with concentration of $150 \mathrm{mg} / \mathrm{l}$ (Photoplate 1, Fig.4). The time required for complete clearing of water with this concentration was $16 \mathrm{hrs}$.

Photoplate No.1

\section{Volume 6 Issue 1, January 2017




\section{International Journal of Science and Research (IJSR) \\ ISSN (Online): 2319-7064}

Index Copernicus Value (2015): 78.96 | Impact Factor (2015): 6.391

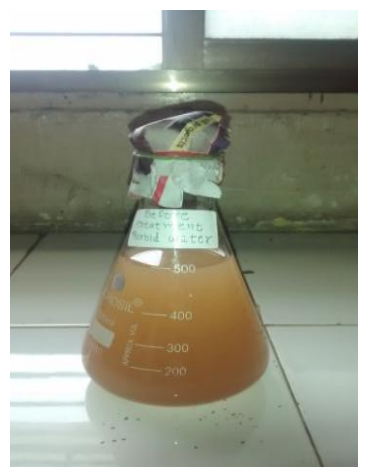

Figure 1: Untreated ground open well water sample
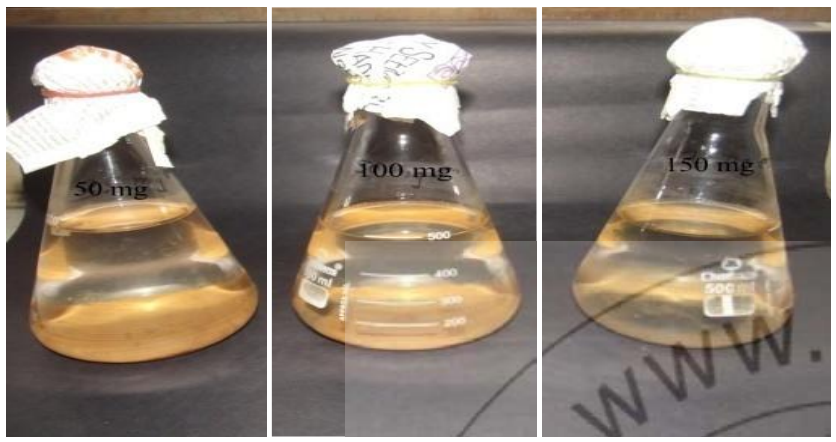

Figure 2: Flask with Fig.3 Flask with Fig.4 Flask with $50 \mathrm{mg} / 1$ conc $^{\text {on }} 100 \mathrm{mg} / 1$ conc $^{\text {on }} 150 \mathrm{mg} / 1$ conc $^{\text {on }}$

Moringa oleifera seed powder treatment showing flasks after $16 \mathrm{hrs}$.

\section{Result and Discussion}

In present study, during the analysis it was observed that after treatment with Moringa oleifera seed powder ; The analysis showed that the seed powder of Moringa oleifera at all the concentrations used is natural and powerful coagulant, especially at $150 \mathrm{mg} / 1$ concentration it has reduced turbidity which is below WHO/USPH standards. There was an improvement in the flock size and flock settled rapidly i.e. within $16 \mathrm{hrs}$.

Thus, the most effective dose of Moringa oleifera seed powder is $150 \mathrm{mg} / \mathrm{l}$.

\section{Conclusion}

Moringa oleifera seed powder acts as a natural coagulant, flocculant, absorbent for the treatment of ground open well water. It is most clear at the dose of $150 \mathrm{mg} / \mathrm{l}$. Thus we conclude that seed powder of Moringa oleifera is natural coagulant. It is ecofriendly and proves to be cheaper method of water treatment. Moringa oleifera seeds can be used in the rural areas to treat turbid drinking water where no other facilities are available for the drinking water treatment.

\section{References}

[1] Amagloh and Benang, (2009) Effectiveness of Moringa oleifera seeds as a coagulant for water purification, University for Development Studies, Faculty of Applied Sciences, Department of Applied Chemistry and Biochemistry, P.O. Box 24, Navrongo, Ghana.
[2] Madsen M., Schlundt J. and Omer E. F., (1987) Effect of water coagulation by seeds of $M$. oleifera on bacterial concentration, J. Trop. Med. Hyg., 1, 90-109.

[3] Maithi S.K. (2004) Handbook of methods in environmental studies vol.1: water and waste water analysis, second edition, published by ABD publisher, Jaipur - 302015.

[4] Mangale Sapana M., Chonde Sonal G. and Raut P. D. , (2012) Use of Moringa oleifera (Drumstick) seed as Natural Absorbent and an Antimicrobial agent for Ground water Treatment, Research Journal of Recent Sciences, 1(3), 31-40.

[5] Eilert U., Wolters B. and Nahrstedt, (1981) The antibiotic principle of using Moringa oleifera and Moringa stenopetalla Plant medical, 42, 55-61.

[6] Suleyman A. Muyibi and Lilian M. Evison,(1994) "Moringa oleifera seeds for softening hard water", Department of Civil Engineering, University of Newcastle upon Tyne, Newcastle upon Tyne NEI 7RU, England, Wat. Res. 29(4), 1099-1105. 